\title{
Development of Software for Design of Soil and Water Conservation Structures in Watershed
}

\author{
S.B.Nandgude \\ Associate Professor \\ Dept. of Soil and Water \\ Cons. Engg. \\ DBSK Agril. Univ., \\ Dapoli, India
}

\author{
N.N.Solaskar \\ Lecturer \\ CS Dept \\ VP's ASC College, \\ Baramati, India
}

\author{
V.U.Kulkarni \\ Dept. of Soil and \\ Water Cons. Engg. \\ DBSK Agril. Univ., \\ Dapoli, India
}

\author{
P.A. Bandekar \\ Dept. of Soil and \\ Water Cons. Engg. \\ DBSK Agril. Univ., \\ Dapoli, India
}

\author{
D.M.Mahale \\ Professor and Head \\ Dept. of Soil and \\ Water Cons. Engg. \\ DBSK Agril. Univ., \\ Dapoli, India
}

\begin{abstract}
Watershed management with focus on reduction of runoff and soil erosion by design of location specific engineering structures is essential. Watershed Softguide is the software for design of three structures: bench terrace, farm pond and vegetated waterway, which are very important for conservation of natural resources in environmentally sensitive era. This software has been supported with database that contains data of 150 locations all over Maharashtra State in India to make the design location specific. The software is armed with database addition and editing facility. It also gives to-the scale diagram of the designed structure, which can be printed. Help-pan present on the screen makes it user-friendly. The software has been tested at developer's level. Results obtained using software were compared with on-paper calculation and the results were found satisfactory. Watershed Softguide 1.0 software has lead to the simplification of the design of soil and water conservation structures is achieved to an extent that field officers and farmers can design those structures in their respective locations with easily and readily available information.
\end{abstract}

\section{Keywords}

Bench terrace, vegetated waterway, farm pond, design.

\section{INTRODUCTION}

Maharashtra state in India is characterized with high range of rainfall in various parts of state. High intensity rainfall and slope are causing irreparable damage in the form of very severe soil erosion ranging from 5 to 33 tones per ha per year[9]. Realizing the need for sufficient productive land to meet the demands of burgeoning population with minimal or ideally no deforestation, erosion control measures have to be undertaken with scientific approach. Since soil erosion is intricately related to rainfall, runoff, land cover and land use[20], conservation measures require scientific design based on available information about land, climate, crop and financial resources[1,11]. With this software we are looking forward to simplify the design of soil and water conservation structures so that a farmer can design those structures in his own style[3].

Watershed Softguide 1.0 software has been developed with objective of extensive use by extension workers, government agencies, field officers and farmers. With above-said focus inbuilt database was created. So that minimum data may be asked from user. It was also provided with soil database addition and editing facility, which improved its adoptability for wider reach, even for other states[8]. Help pan provided on the screen made the software available for instant use as former acts as user manual. Wizard type interface develop for making the operations easier.

This software has been provided with strong input validation framework, so incorrect/invalid data is blocked. This software also gives the help tips about current screen[15]. To the scale graphical diagrams of the soil and water conservation structures made the software more explanatory and acceptable at all levels. Optional cost estimation facility has brought the added advantage to this software.

\section{MATERIALS AND METHOD}

\subsection{Platform}

The software for design of various soil and water conservation structures was developed using Microsoft Visual Basic 6.0 Enterprise Edition with Service Pack 6, for 32-bit Windows Development and Microsoft Access 2000 (9.0.2720) for backend[6,12,16].

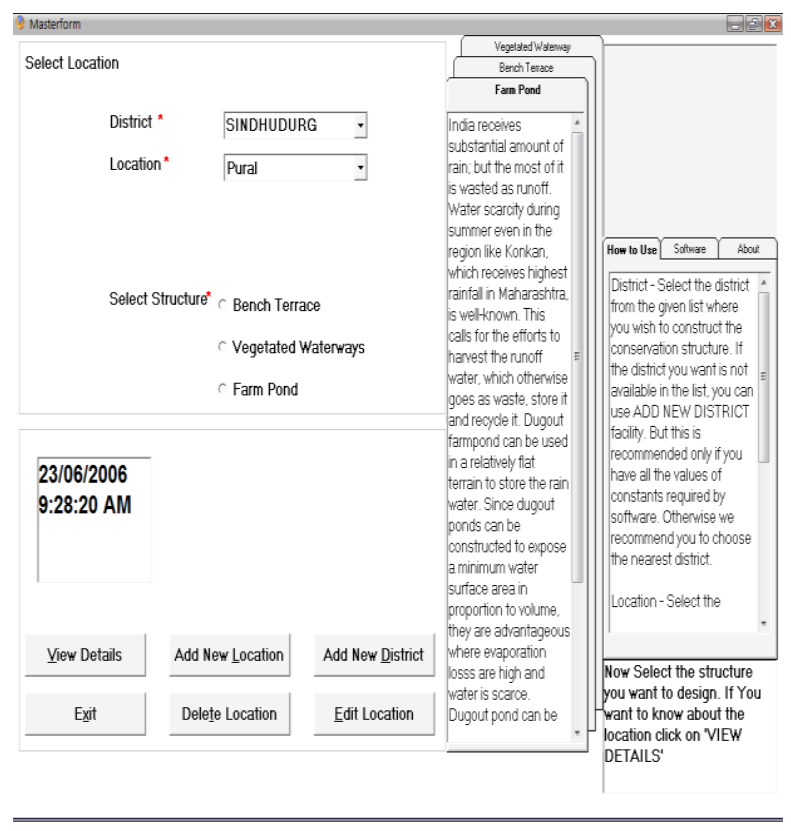

Figure1: Software Interface

\subsection{Minimum System Requirements}

Intel® Pentium ${ }^{\mathrm{TM}}$ III $700 \mathrm{MHz}$ or equivalent processor 


\section{MB RAM}

30 MB Hard disk space.

VGA display with $1024 \square 768$ Pixels resolution.

\section{ROM drive.}

Microsoft ${ }^{\circledR}$ Windows ${ }^{\mathrm{TM}} 98$ or above.

Microsoft ${ }^{\circledR}$ Visual Basic Runtime Installed.

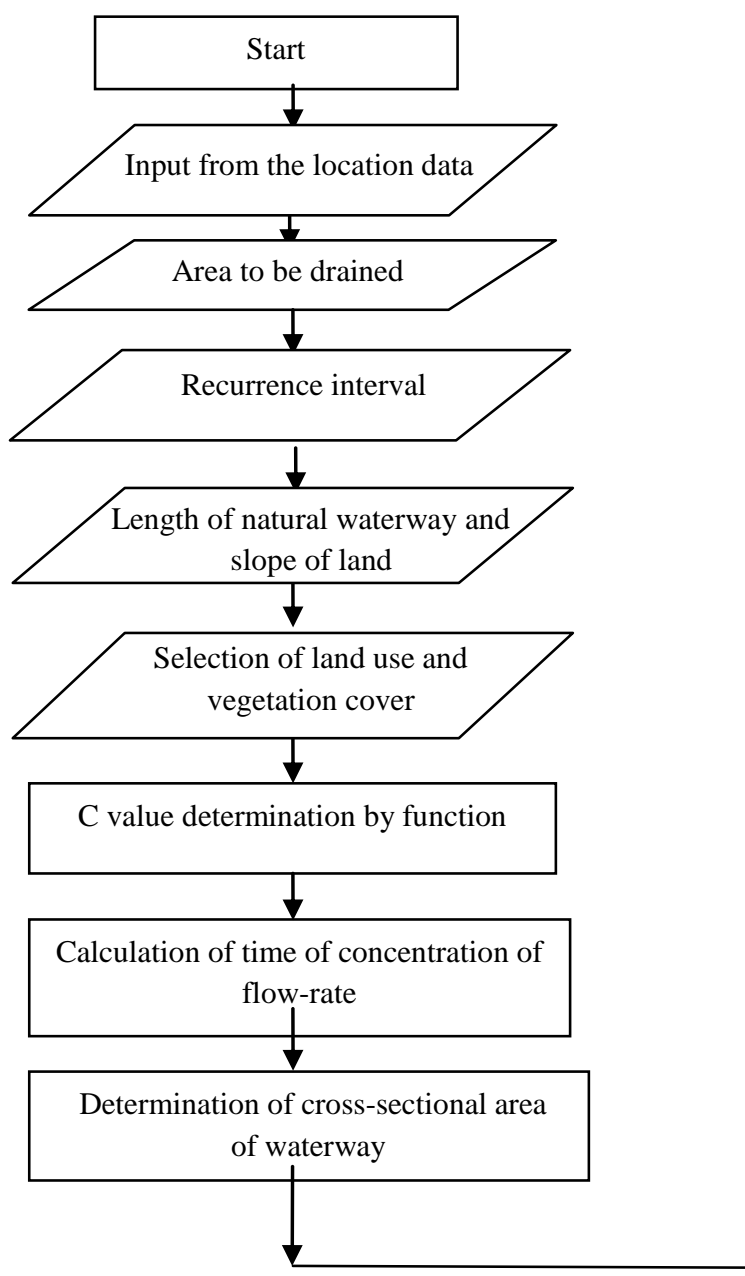

Figure 2: Flowchart for design of vegetated waterways

\subsection{Design of Vegetated Waterways}

A trapezoidal section with a slight ' $\mathrm{V}$ ' bottom can be easily constructed where the waterway is artificially located. Though maximum permissible grade of waterway is 10 per cent, it is normally kept below 5 cent to avoid scouring[17]. Standard engineering design procedure is followed with logical assumptions and steps as briefly shown in flowchart in Fig.2[19]. Cost of excavation was calculated by multiplying earthwork required by cost of excavation per cubic meter. Cost of sodding was calculated from total length to be sodded by cost of sodding per $100 \mathrm{~m}$. Total cost of waterway was determined by adding cost of excavation and cost of sodding[21]

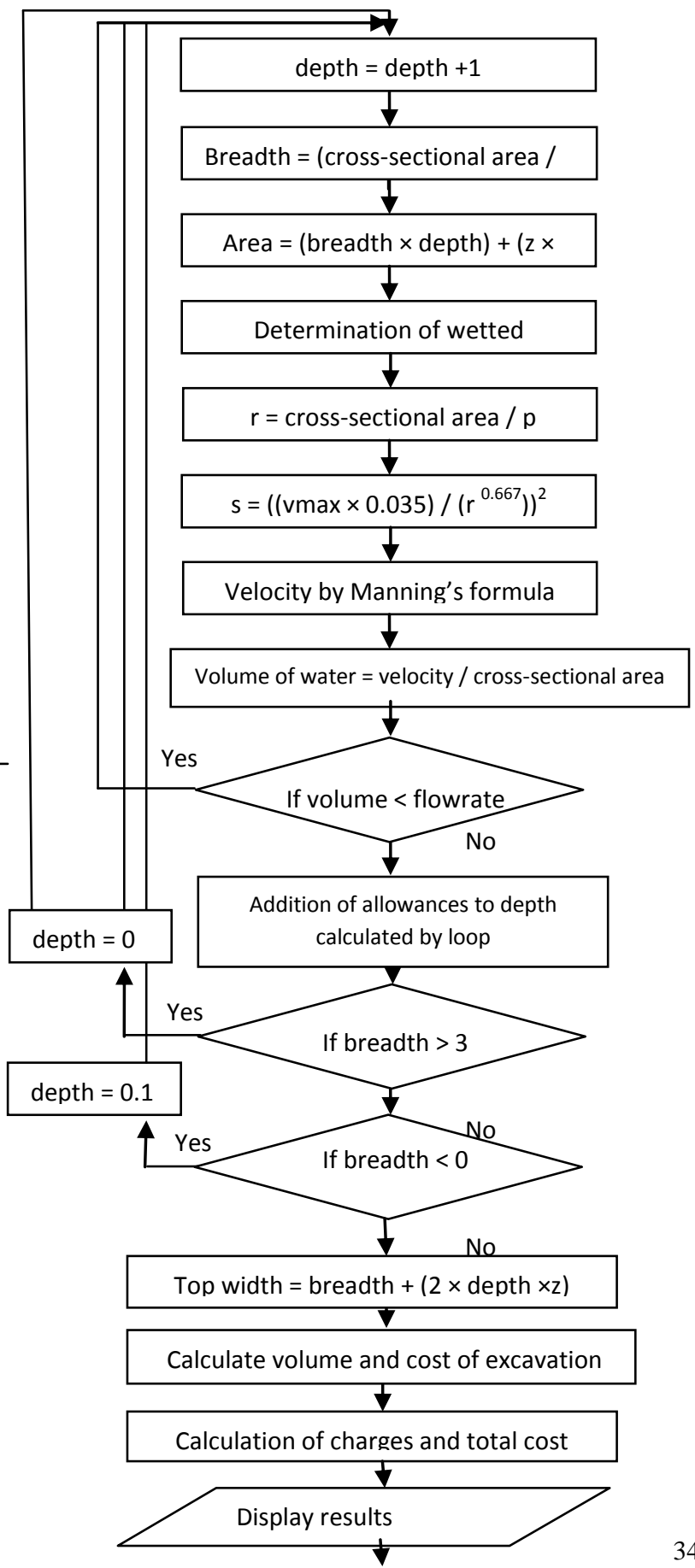




\subsection{Design of Bench Terrace}

Bench terracing is a method of erosion control, practiced in the steep slopes, accomplished by constructing broad channels across the slope. It consists converting original sloping ground in to step-like fields along contours by half-cutting and halffilling. In rainfed areas, bench terracing is generally practised in 16-33\% slope range. However, level bench terracing is recommended for paddy fields even on the mild slopes of $1 \%$ for uniform impounding of water.[10,13]

Bench terraces have three types:

1. Level bench terrace- used for paddy growing areas

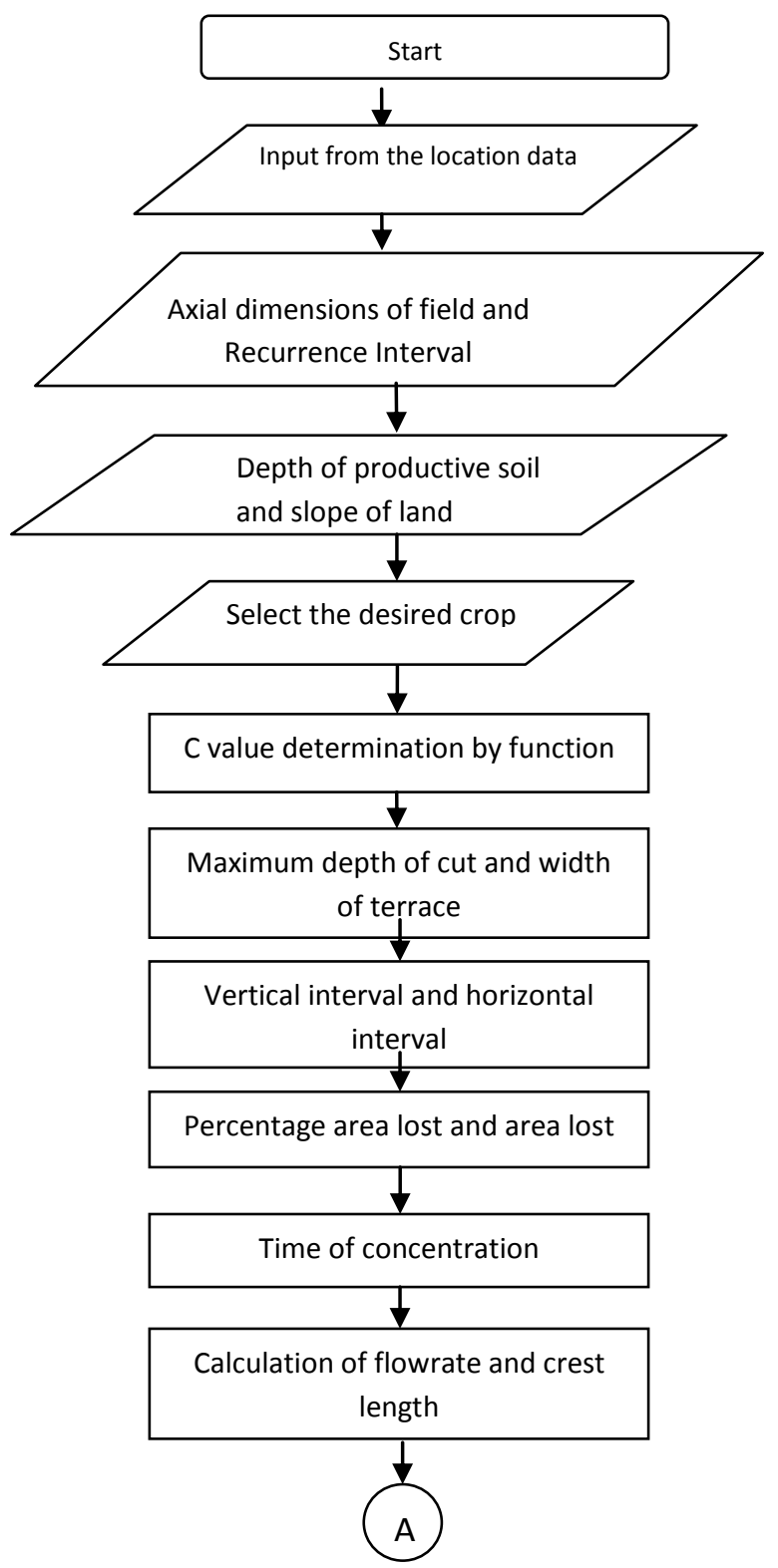

2. Inwardly sloping bench terrace- used for crops susceptible to water logging and where quick disposal of runoff is necessary.

3. Outwardly sloping bench terrace- this is a step toward level or inwardly sloping bench terrace used in regions with low rainfall and shallow soil depth.

Standard engineering design procedure is followed with logical assumptions and steps as briefly shown in flowchart in Fig.3[17,19]. Total earthwork required was determined by multiplying earthwork per ha by field area. Total batter length to be sodded was also determined. From cost of earthwork per cubic meter and cost of sodding per $100 \mathrm{~m}$ total cost of bench terrace was calculated[21].

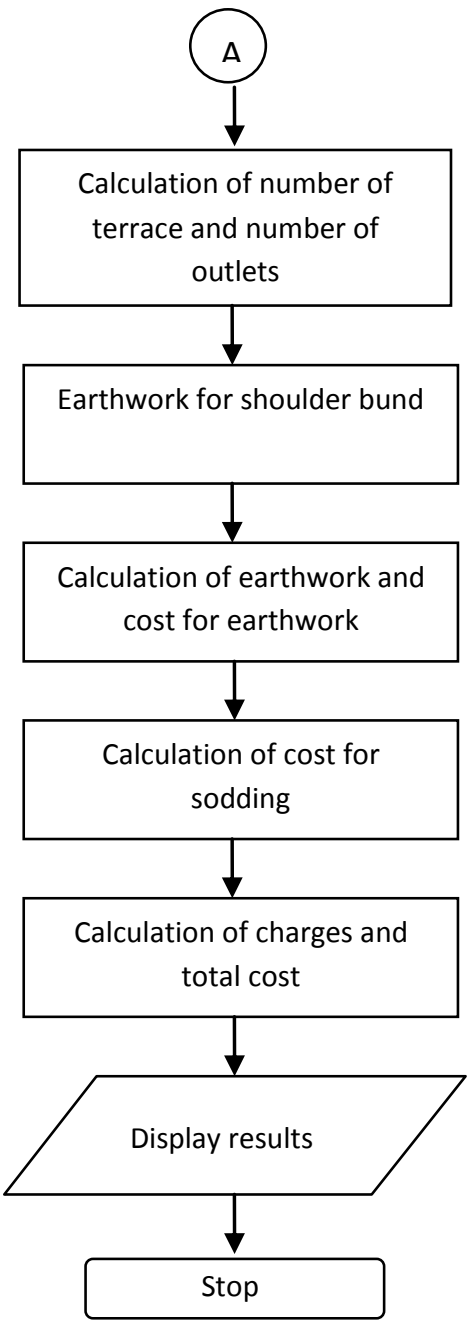

Figure 3: Flowchart for design of bench terrace

\subsection{Design of Farm Pond}

Average annual rainfall in various parts of Maharashtra State ranges from about $500 \mathrm{~mm}$ to $4000 \mathrm{~mm}$ but dearth of water during summer is very common. This calls for assiduous efforts to harvest rain water and reusing it when 
natural sources of water are dried up. This can be achieved by constructing farm ponds.

Standard engineering design procedure was used for design of dugout farm pond[17,19].

a. Volume of water to be stored was determined from human population, population of cattle and poultry birds, number of horticultural trees, area under agronomical and vegetable crops to be irrigated and other miscellaneous uses with standard water requirements[2,5,7,14,18]. Care was taken to keep the depth within range of 3 to $5 \mathrm{~m}[4]$.
Cost $\mathrm{A}=$ cost of excavation + cost of lining + other miscellaneous cost

Total cost $=$ Cost $A+2 \%$ of Cost $A$

d. Cost per litre was calculated as follows

Cost $\mathrm{B}=$ cost of excavation+ (cost of lining/3) + other miscellaneous cost

Cost per litre $=(1.02 *$ Cost B $) /$ Capacity of pond

Flowchart for design of farm pond is given in Fig. 4

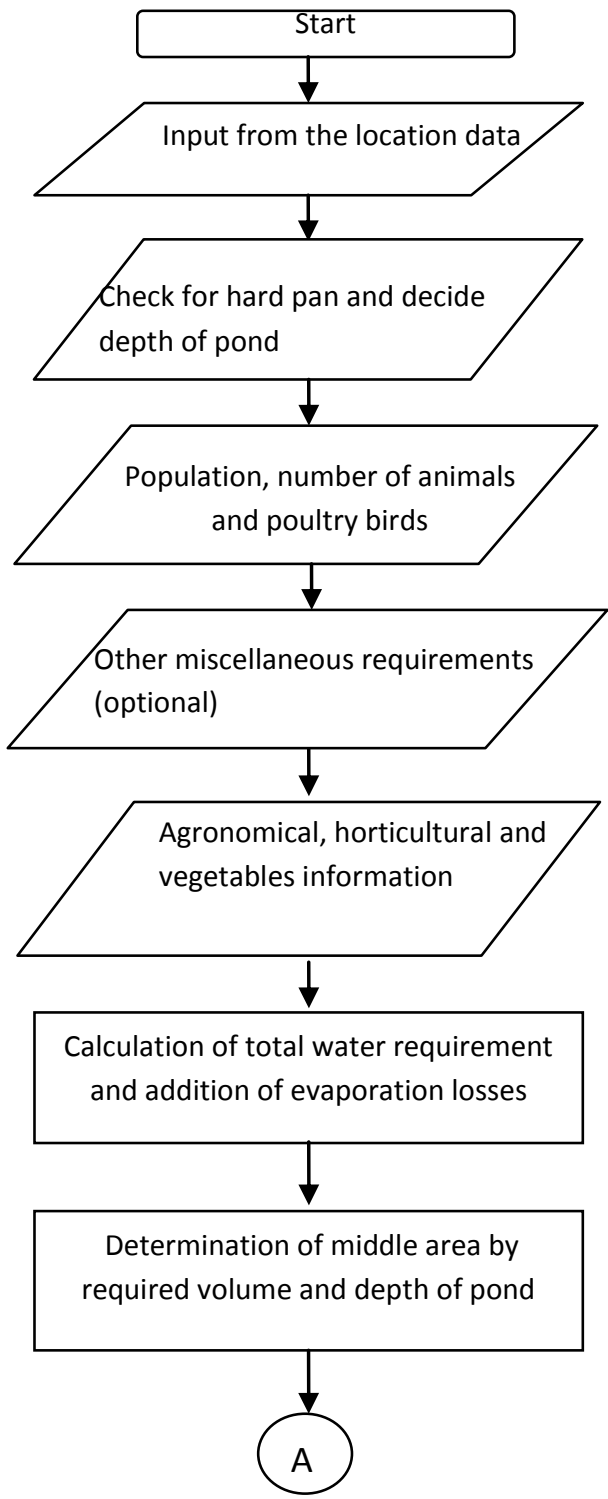

Figure 4: Flowchart for design of farm pond

b. Rectangular pond with trapezoidal crosssection was chosen as it is easy to construct. The side slope was taken as 1:1.

c. Total cost of pond was calculated as follows

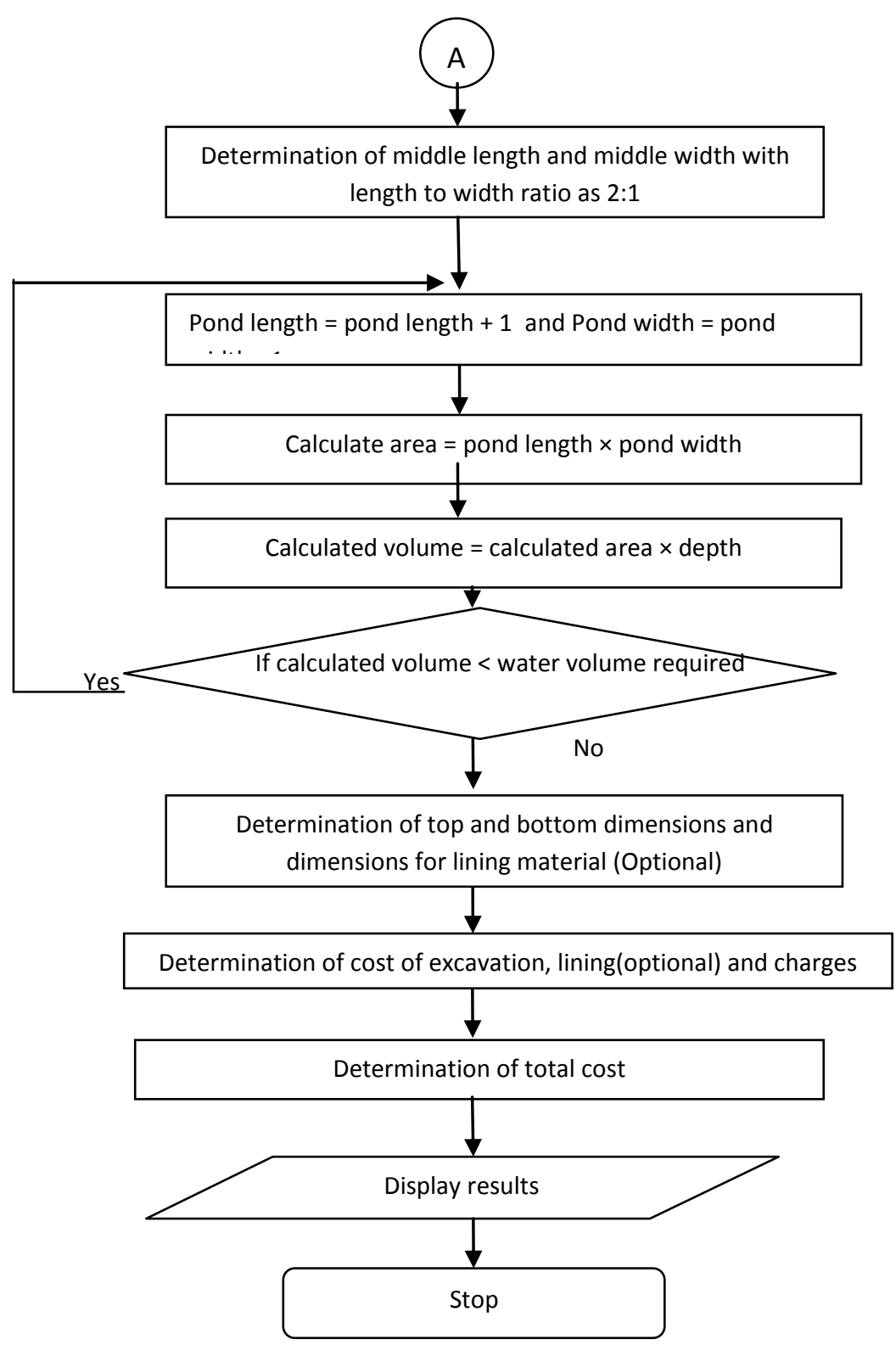

3. RESULTS AND DISCUSION

Software results for Pural watershed in Sindhudurg district of Maharashtra are given here. 


\subsection{Design for Vegetated Waterway}

Input form and result from of vegetated waterway are given in fig. 5 and fig. 6

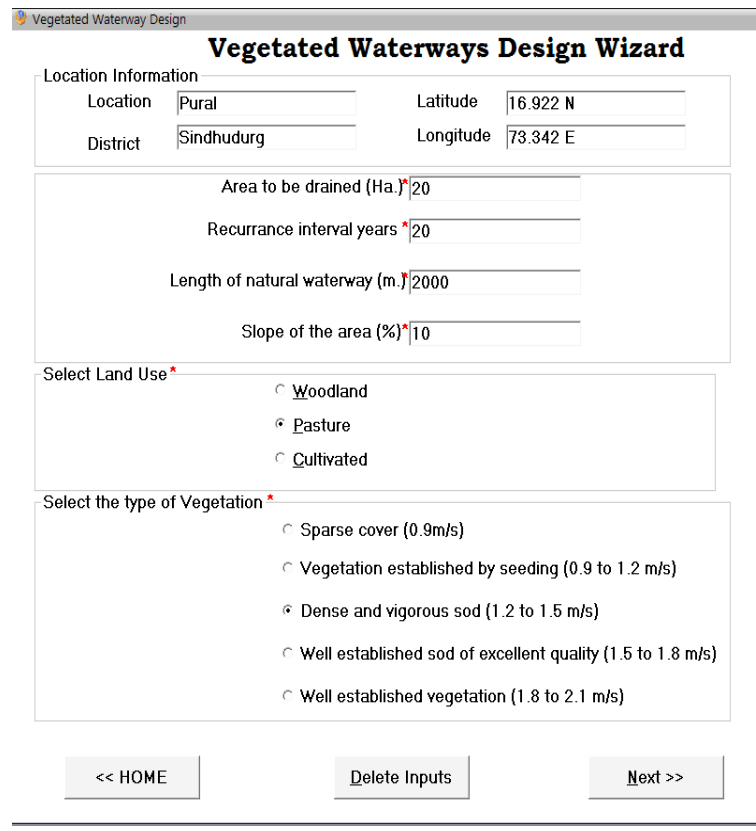

Figure 5: Vegetated Waterway Input Form

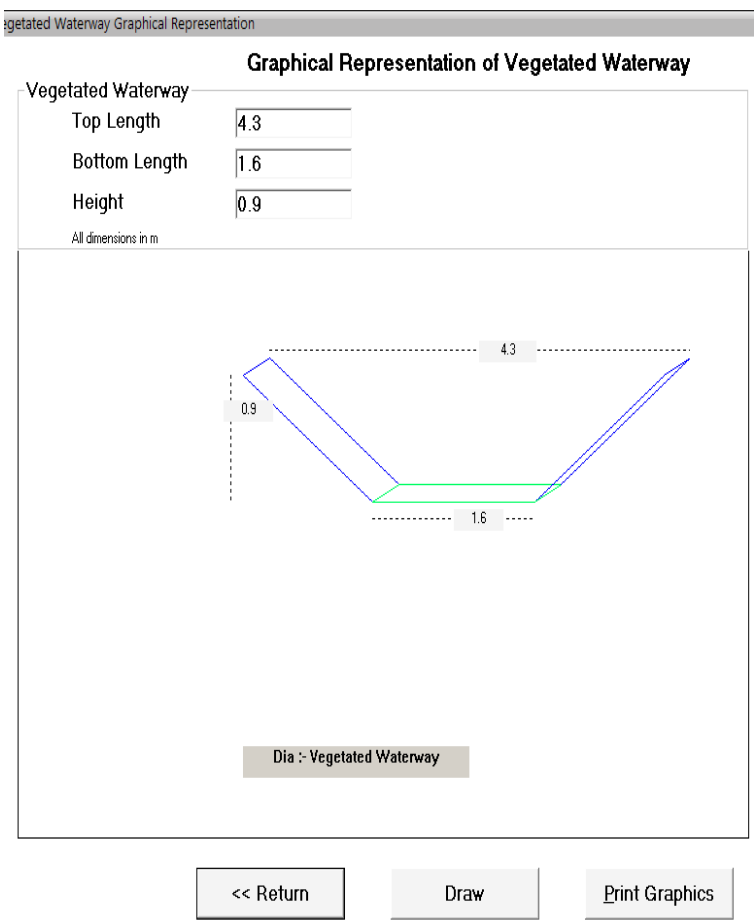

Figure 6:Vegetated Waterway Result Form

For testing purpose we compared the software designs values with the standard design procedure values the summary is as follows.

\subsubsection{Comparison of Design for Vegetated \\ Waterway}

Table 1: Comparison of output

\begin{tabular}{|c|c|c|}
\hline Parameters & $\begin{array}{c}\text { Software } \\
\text { Output }\end{array}$ & $\begin{array}{c}\text { Calculated } \\
\text { Output }\end{array}$ \\
\hline Peak runoff rate & 2.22 cumec & 2.224 cumec \\
\hline Total depth of waterway & $0.9 \mathrm{~m}$ & $0.9 \mathrm{~m}$ \\
\hline Bottom width of waterway & $1.6 \mathrm{~m}$ & $1.57 \mathrm{~m}$ \\
\hline Top width of waterway & $4.3 \mathrm{~m}$ & $4.3 \mathrm{~m}$ \\
\hline Total cost of construction & $\begin{array}{c}\text { Rs. } \\
203,286 /-\end{array}$ & $\begin{array}{c}\text { Rs. } \\
203,286 /-\end{array}$ \\
\hline
\end{tabular}

\subsection{Design for Bench Terrace}

Input form and result from of bench terrace are given in fig.7 and fig. 8

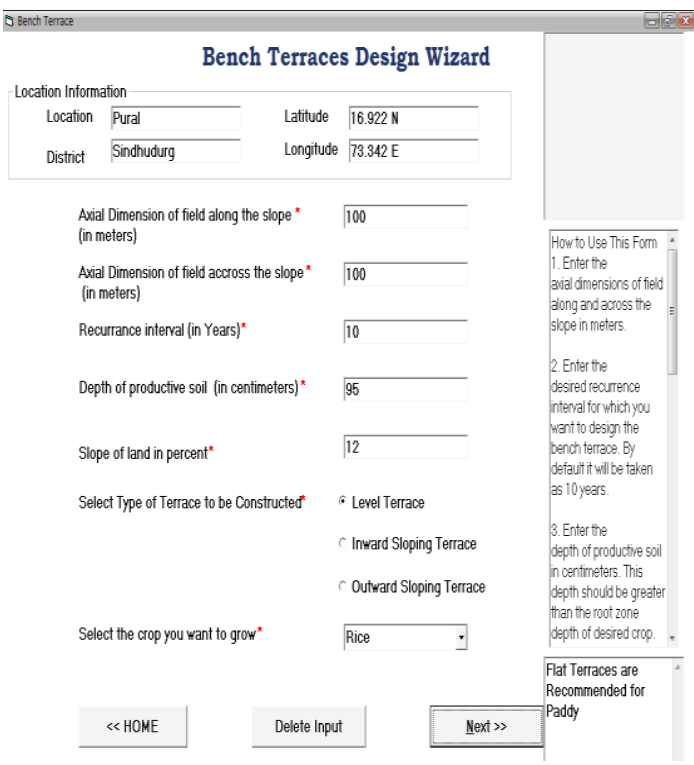

Figure7: Bench Terrace Input Form 


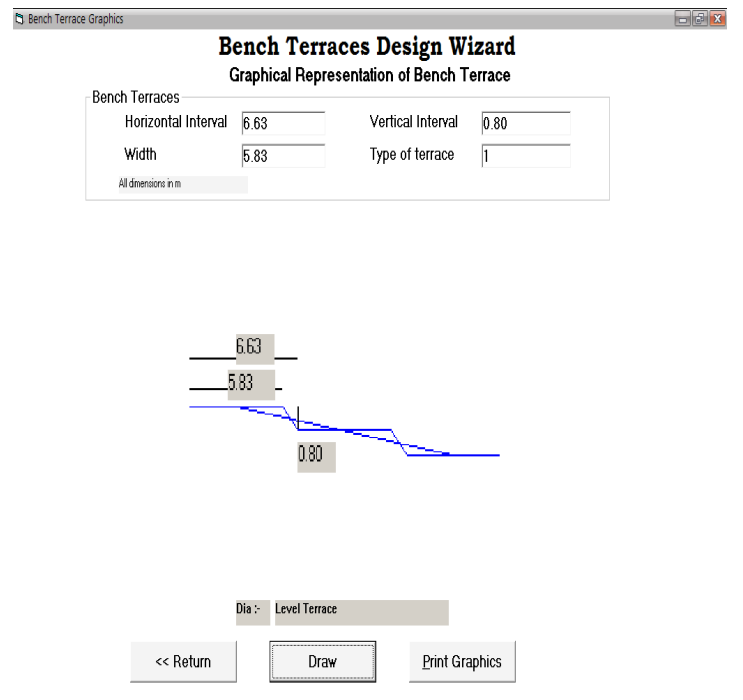

Figure 8: Bench Terrace Design Result

\subsubsection{Comparison of Design for Bench Terrace a. $\quad$ Crop= Paddy}

\section{Table 2: Comparison of output}

\begin{tabular}{|c|c|c|}
\hline Parameters & $\begin{array}{c}\text { Software } \\
\text { Output }\end{array}$ & $\begin{array}{c}\text { Calculated } \\
\text { Output }\end{array}$ \\
\hline Vertical interval & $0.68 \mathrm{~m}$ & $0.68 \mathrm{~m}$ \\
\hline Horizontal interval & $5.68 \mathrm{~m}$ & $5.68 \mathrm{~m}$ \\
\hline Width of Terrace & $5 \mathrm{~m}$ & $5 \mathrm{~m}$ \\
\hline Total number of outlets & 18 & 18 \\
\hline Height of shoulder bund & $0.3 \mathrm{~m}$ & $0.3 \mathrm{~m}$ \\
\hline $\begin{array}{c}\text { Top width of shoulder } \\
\text { bund }\end{array}$ & $0.15 \mathrm{~m}$ & $0.15 \mathrm{~m}$ \\
\hline $\begin{array}{c}\text { Bottom width of shoulder } \\
\text { bund }\end{array}$ & $0.75 \mathrm{~m}$ & $0.75 \mathrm{~m}$ \\
\hline Total cost of construction & Rs. $46,618 /-$ & Rs $46,618 /-$ \\
\hline
\end{tabular}

\subsection{Design for Farm Pond}

Input form and result from of bench terrace are given in fig. 9 and fig. 10

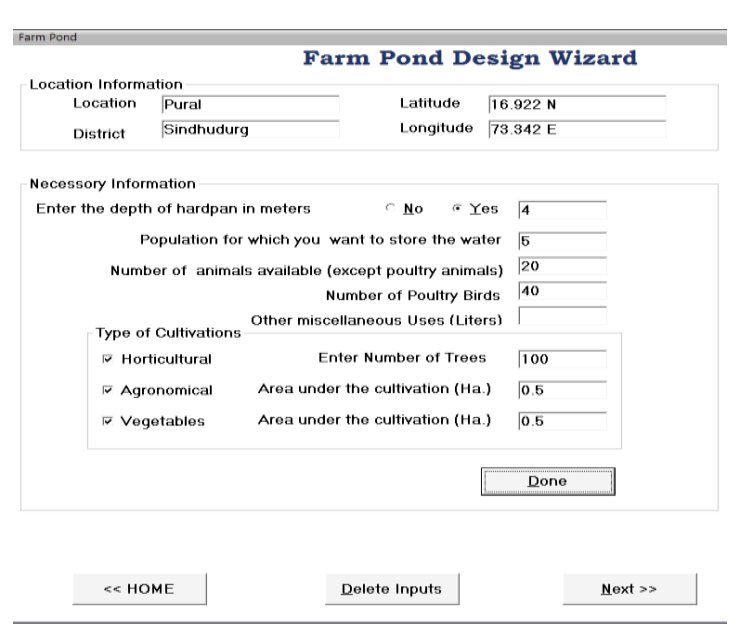

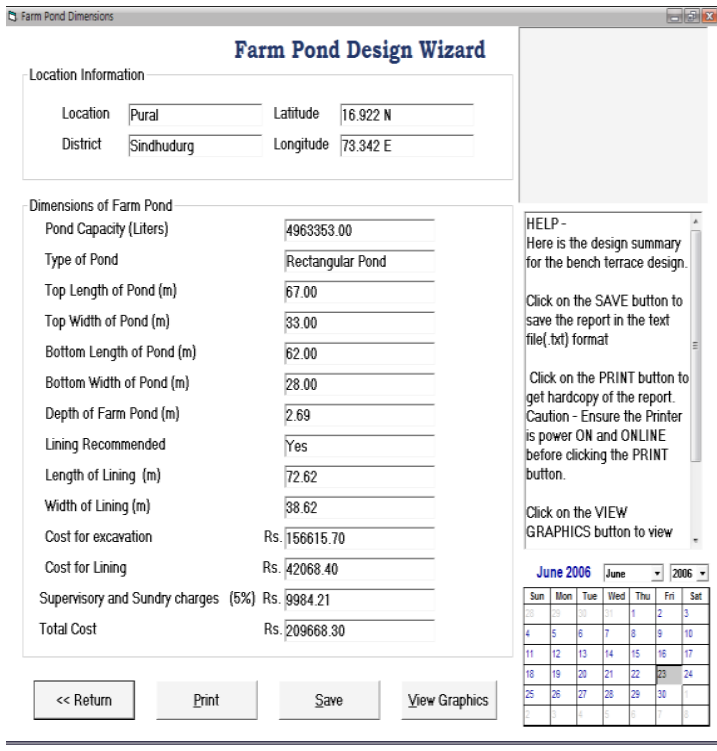

Figure10: Farm Pond Design Results

\subsubsection{Comparison of Design for Farm Pond}

Table 3: Comparison of Output

\begin{tabular}{|c|c|c|}
\hline Parameters & Software Output & Calculated Output \\
\hline Capacity of pond & $4,963,353$ lits & $4,963,353$ lits \\
\hline Top length & $67 \mathrm{~m}$ & $67 \mathrm{~m}$ \\
\hline Top width & $33 \mathrm{~m}$ & $32 \mathrm{~m}$ \\
\hline & & $62 \mathrm{~m}$ \\
\hline Bottom length & $62 \mathrm{~m}$ & $27 \mathrm{~m}$ \\
\hline Bottom width & $28 \mathrm{~m}$ & $2.69 \mathrm{~m}$ \\
\hline Depth of pond & $2.69 \mathrm{~m}$ & $37.6 \mathrm{~m}$ \\
\hline Length of lining & $72.62 \mathrm{~m}$ & Rs. 151204.49 \\
\hline Width of lining & $38.62 \mathrm{~m}$ & Rs. $122,839.20$ \\
\hline Cost of excavation & Rs. $156,615.70$ & Rs. 279,524.56 \\
\hline Cost of lining & Rs. $126,208.20$ & Rs. 0.039 \\
\hline Total cost & Rs. $288,477.30$ & \\
\hline Cost per litre & Rs. 0.04 & \\
& & \\
\hline
\end{tabular}

Figure9: Farm Pond Input Form 


\section{CONCLUSIONS}

1. The software was developed to design bench terrace, vegetated waterway and farm-pond, which are very important soil and water conservation structures in Maharashtra State, India

2. The Software is based on validated data, thus there is hardly any chance to input incorrect/invalid information.

3. Dynamic database is provided with the software which can be updated in order to adopt the software to any other locality by addition of database of respective location.

4. Software is developed by considering the low computer awareness of potential users, supported with help pan and tips to guide the user at every step.

5. Design of structure obtained by software was tested with on-paper calculations at developer's level and results were found satisfactory.

\section{ACKNOWLEDGMENTS}

Our thanks to the honorable Vice-Chancellor and Director of Research of Dr.B.S.Konkan Agricultural University, Dapoli, India who have encouraged us for development of the software "Watershed Softguide"

\section{REFERENCES}

[1] Anonymous. 1990. RUNOFF. International Institute for Land Reclamation and Improvement, Netherlands.

[2] Anonymous. 1998. CropWat 4 Windows Version 4.2. Institute of Irrigation and Development Studies, United Kingdom.

[3] Anonymous. 2001. Soil and Water Conservation Structure Design (SCS Designer) v1.0. Indian Institute of Technology, Kharagpur.

[4] Bhandarkar, D. M.. 1985. Design and feasibility of dugout pond in black soils of Bhopal region. Soil and water engineering. Proceeding of silver jubilee convention. ISAE. Vol-2. III-30-III38

[5] Banarjee, G. S.. 1964. Textbook of Animal Husbundary. pp. 287.

[6] Bradley, J.C. and A. C. Millspaugh. 2001. Programmimg in Visual Basic 6.0. Tata McGraw-Hill Publishing Company Ltd. New Delhi. pp. 86-523
[7] Chadha, K. L.. 2001. Handbook of Horticulture. Indian Council of Agricultural Research. New Delhi. pp. 243.

[8] Challa O., K. S. Gajbhie, M. Yelayutham. 1999. Soil Series of Maharashtra. National Bureau of Soil Survey and Land Use Planning. Nagpur. pp. 7-371

[9] Dhruva Narayana, V. V., G. Sastry, U. S. Patnaik. 1997. Watershed Management. Indian Council of Agricultural Research. New Delhi. pp.49, 57.

[10] Dhruva Narayana, V. V., 1999. Soil and Water Conservation Research in India, Indian Council of Agricultural Research. New Delhi. pp. 138.

[11] Hudson, N. W.. 1993. Field measurement of soil erosion and runoff. FAO Soil Bulletin, Vol- 68, pp. 60, 110

[12] Jerke, N..1999. Complete Reference Visual Basic 6. Tata McGraw-Hill Publishing Company Ltd. New Delhi.. pp. 122-148

[13] Michael, A. M., T. P. Ojha. 1999. Principles of Agricultural Engineering, Vol-II. Jain Brothers. New Delhi. pp. 500, 507, 692, 725, 707, 708

[14] Michael, A. M.. 2000. Irrigation Theory and Practices. Vikas Publishing House Pvt. Ltd.. New Delhi. pp. 510

[15] Petroutsos, E. 1998. Mastering Visual Basic 6. BPB Publications. New Delhi. pp.75-80.

[16] Rob, P. and E. Semaan. 2001. Databases. Tata McGrawHill Publishing Company Ltd. New Delhi. pp. 103-185

[17] Schwab, G. O., D. D. Fangmeier, W. J. Elliot and R. K. Frevert. 1993. Soil and Water Conservation Engineering. John Wiley \& Sons, Inc. pp. 135, 166.

[18] Shrivastava 2001. Invesment Decision Model for Drip Irrigation System. Version 1.0.

[19] Singh G., C. Venkataraman, G. Shastry and B. P. Joshi. 1999. Manual of Soil and Water Conservation Design. Oxford and IBH Publishing Co. Pvt. Ltd. New Delhi. pp. 30, 88-95, 121-128, 145-149.

[20] Subramanya, K.. 2002. Engineering Hydrology. Tata McGraw-Hill Publication Company Ltd.. New Delhi. 235

[21] Tideman, E. M.. 2003. Watershed Management Guideline for Indian Conditions. Omega Science Publishers, New Delhi. 82. 